\title{
Strategi Peningkatan Kompetensi Pedagogik Guru Untuk Meningkatkan Mutu Sekolah
}

\author{
Brigitta Putri Atika Tyagita \\ SMA Karangturi Semarang \\ brigittaputriatika@gmail.com \\ Ade Iriani \\ Magister Manajemen Pendidikan Universitas Kristen Satya Wacana \\ ade.iriani@staff.uksw.edu
}

\begin{abstract}
This study aimed to obtain a strategy to increase the pedagogic competence of teacher to improve school quality. Teacher pedagogy competencies are important to have so that the teacher can understand and direct students to learn well and appropriately, and can help students to actualize their potential. Pedagogy competence of teachers can improve the school quality because one of them seen from a professional teacher and good performance. The subject of this study: 1 principal, 1 vice principal, 6 teachers. The research data was taken through an interview, observation, and document study with source triangulation. Data analysis using SWOT to analyze internal and external factors. The results of the SWOT analysis shows that schools are in the SO or strength-opportunity quadrant, which supports aggressive strategies by utilizing the strengths and opportunities that schools have to improve teacher pedagogic competence. By optimizing the strength factor and the school opportunity, there are 6 strategic plans to increase the pedagogic competence of teachers by emphasizing cooperation among teachers, students and also parents. The strategic plan is to optimize the performance of leaders, optimize collaboration among teachers, the collaboration between teachers and students, optimize external support, optimize teacher pedagogical development, and improve teacher, student, and parent collaboration.
\end{abstract}

Keywords: Teachers Pedagogic Competence, School Quality, Strategic Plan, SWOT Analysis

\section{Article Info}

Received date: 4 Mei $2017 \quad$ Revised date: 13 November $2018 \quad$ Accepted date: 9 Desember 2018

\section{PENDAHULUAN}

Kualitas pendidikan di Indonesia saat ini masih jauh dari Negara-negara lainnya, dimana Indonesia menempati peringkat ke 10 dari 14 negara berkembang dalam pendidikan, dan kualitas guru di Indonesia berada diperingkat ke 14 dari 14 negara berkembang di dunia (Fahruddin, 2016:1). Hasil uji kompetensi guru di Indonesiapun masih rendah dan masih jauh dari yang ditargetkan oleh pemerintah dengan nilai rata-rata 41,5 dengan nilai terendah 1 dari 275.768 guru tingkat nasional (Inan, 2016: 1). Untuk meningkatkan kualitas pendidikan di Indonesia, pemerintah telah menetapkan Standar Nasional Pendidikan yang merupakan dasar dalam perencanaan, pelaksanaan, dan pengawasan pendidikan dalam rangka mewujudkan pendidikan yang bermutu (Peraturan Pemerintah No. 19 Tahun 2005: 6) yang mencakup 8 aspek, yaitu standar isi, standar proses, standar kompetensi lulusan, standar pendidik dan tenaga kependidikan, 
Kelola: Jurnal Manajemen Pendidikan, Vol. 5, No. 2, Juli-Desember 2018

standar sarana dan prasarana, standar pengelolaan, standar pembiayaan, dan standar penilaian pendidikan.

Melihat permasalahan yang dihadapi oleh pendidikan Indonesia, maka untuk meningkatkan kualitas pendidikannya, kualitas guru harus ditingkatkan terlebih dahulu salah satunya dengan meningkatkan kompetensi pedagogik guru. Jika ingin meningkatkan kompetensi lulusan maka kualitas guru dalam proses belajar mengajar harus ditingkatkan (Guerriero, 2013: 2). Oleh sebab itu untuk meningkatkan kualitas pendidikan Indonesia, maka kualitas guru harus ditingkatkan, salah satunya dengan meningkatkan kompetensi pedagogik guru untuk meningkatkan mutu sekolah. Oleh sebab itu diperlukan strategistrategi dalam meningkatkan kompetensi pedagogik guru untuk meningkatkan mutu sekolah.

Kompetensi pedagogik guru penting untuk ditingkatkan, karena kompetensi pedagogik guru akan meningkatkan kompetensi profesionalisme guru dalam mengajar, karena dengan memiliki kompetensi pedagogik, maka guru memiliki kemampuan dalam mengatur materi pembelajaran yang akan disampaikan dengan baik kepada muridmuridnya dengan berbagai teknik (Rahman, 2014: 79). Menurut Panda (2012: 34) kompetensi pedagogik guru merupakan kemampuan dan keinginan untuk secara regular menerapkan sikap, pengetahuan, dan keahliankeahlian untuk mempromosikan pembelajaran dari guru dan murid. Kompetensi pedagogik guru menurut Uppsala University (2010: 10) adalah tujuan dan kerangka kerja guru yang pasti melalui pengembangan pembelajaran dan pengembang an profesionalisme, dukungan, dan fasilitas pembelajaran yang terbaik secara berkelanjut-an. Sedangkan menurut Hakim (2015: 2) kompetensi pedagogik guru adalah kemampuan mengatur pembelajaran, kerangka instruksi dan implementasi, hasil evaluasi pembelajaran, dan pengembangan siswa untuk mengaktualisasikan potensi mereka. Dari pengertian tersebut dapat disimpulkan bahwa kompetensi pedagogik guru adalah kemampuan dan keinginan dalam menerapkan sikap, pengetahuan dan keahlian untuk mempromosikan pembelajaran, mengatur pembelajaran, dan mengevaluasi serta membantu siswa untuk dapat mengaktualisasikan potensi mereka.

Standar kompetensi pedagogik guru telah diatur dalam Peraturan Menteri Pendidikan Nasional No.16 tahun 2007, yang meliputi 10 Kompetensi Inti dan Kementrian Pendidikan Nasional Direktorat Jenderal Peningkatan Mutu Pendidik dan Tenaga Kependidikan (2010, 39-51) sebagai tertera dalam tabel 1 di bawah ini.

Standar kompetensi pedagogik memuat beberapa subkompetensi yaitu, 1) menguasai karakteristik peserta didik dari aspek fisik, moral, sosial, budaya, kultural, emosional dan intelektual. 2) menguasai teori belajar dan prinsip-prinsip pembelajaran yang mendidik. 3) mengembangkan kurikulum yang berkaitan dengan mata pelajaran/bidang pengembangan yang diampu. 4) menyelenggarakan pembelajaran yang mendidik 5) memanfaatkan teknologi informasi dan komunikasi untuk kepentingan pembelajaran 6) memfasilitasi pengembangan potensi peserta didik dan membantu pengembangan potensi peserta didik untuk mengaktualisasikan berbagai potensi yang dimiliki. 7) berkomunikasi secara efektif, empatik, dan santun dengan peserta didik. 8) menyelenggarakan penilaian dan evaluasi proses dan hasil belajar. 9) memanfaatkan hasil penilaian dan evaluasi untuk kepentingan pembelajaran. 10) melakukan tindakan reflektif untuk peningkatan kualitas pembelajaran. 
Tabel 1. Komponen Kompetensi Pedagogik Guru

Peraturan Menteri Pendidikan Nasional

no. 16 tahun 2007

Kementrian Pendidikan Nasional Direktorat Jenderal Peningkatan Mutu Pendidik dan

Tenaga Kependidikan 2010

1. Menguasai karakteristik peserta didik dari aspek fisik, moral, 1. Menguasai karakteristik peserta didik sosial, kultural, emosional, dan intelektual

2. Menguasai teori belajar dan prinsip-prinsip pembelajaran yang 2. Menguasai teori belajar dan prinsipmendidik prinsip pembelajaran yang mendidik

3. Mengembangkan kurikulum yang berkaitan dengan mata 3. Pengembangan kurikulum pelajaran yang diampu

4. Menyelenggarakan pembelajaran yang mendidik 4 4. Kegiatan pembelajaran yang mendidik

5. Memanfaatkan teknologi informasi dan komunikasi untuk 5. Pengembangan potensi peserta didik kepentingan pembelajaran

6. Memfasilitasi pengembangan potensi peserta didik untuk 6. Komunikasi dengan peserta didik mengaktualisasikan berbagai potensi yang dimiliki

7. Berkomunikasi secara efektif, empatik, dan santun dengan peserta 7. Penialaian dan evaluasi. didik

8. Menyelenggarakan penilaian dan evaluasi proses dan hasil belajar

9. Memanfaatkan hasil penilaian dan evaluasi untuk kepentingan pembelajaran

10. Melakukan tindakan reflektif untuk peningkatan kualitas pembelajaran.

Sumber: Data dokumen pemerintah

Rencana strategis merupakan proses disiplin untuk membuat kunci keputusan dan menyetuju tindakan yang akan membentuk dan menimbang apa yang dilakukan suatu organisasi, dan mengapa melakukannya (CIRR ICD, 2005: 44). Rencana strategis merupakan landasan dari setiap kepentingan yang sama dalam komunitas atau organisasi, dan tanpa rencana strategis maka organisasi tidak tahu arah pergerakan atau tujuan dari organisasi (Juddy, 2014: 4). Rangkuti (2016: 3) menambahkan tujuan utama dari rencana strategis adalah agar organisasi dapat melihat secara objektif kondisi-kondisi internal dan eksternal, sehingga organisasi dapat mengantisipasi perubahan lingkungan eksternal. Dari pengertian-pengertian tersebut, maka rencana strategis adalah proses disiplin untuk membuat kunci keberhasilan dan landasan dari setiap kepentingan yang sama dalam suatu organisasi dengan tujuan organisasi dapat melihat secara objektif kondisi internal maupun eksternal, sehingga organisasi dapat mengantisipasi perubahan lingkungan.

Mutu mengandung makna derajat keunggulan suatu produk atau hasil kerja, baik berupa barang atau jasa (Danim, 2010: 53). Pendapat tersebut dipertegas oleh pendapat
Umiarso dan Gozali (2010: 125-126) yang mengatakan bahwa mutu pendidikan adalah derajat keunggulan dalam pengelolaan pendidikan secara efektif dan efisien untuk melahirkan keunggulan akademis dan ekstrakurikuler pada peserta didik yang dinyatakan lulus pada suatu jenjang pendidikan atau menyelesaikan program pendidikan tertentu. Mutu juga merupakan hal yang penting yang harus dimiliki oleh sekolah, karena mutu sekolah menjadi pandangan penting atau pertimbangan bagi orang tua untuk menyekolahkan anak mereka, dan ukuran sekolah bermutu dari kacamata pengguna pada umumnya adalah sekolah dengan akreditasi A, lulusan diterima disekolah terbaik, guru yang profesional yang ditunjukan dengan hasil UKG (Uji Kompetensi Guru) dan kinerja guru baik, hasil ujian nasional baik, peserta didik memiliki prestasi dalam berbagai kompetisi, dan peserta didik memiliki karakter yang baik (Sani, 2015: 1-2). Mutu sekolah merupakan derajad keunggulan yang dimiliki oleh sekolah dan merupakan hal penting yang harus dimiliki oleh sekolah karena mutu sekolah menjadi bahan pertimbangan bagi orang tua untuk menyekolahkan anaknya. Mutu sekolah dapat dilihat dari akrediatasi sekolah, lulusan yang 
Kelola: Jurnal Manajemen Pendidikan, Vol. 5, No. 2, Juli-Desember 2018

diterima di sekolah terbaik, guru yang profesional dan kinerja yang baik, hasil ujian yang baik, peserta didik yang berprestasi dan berkarakter baik.

Meningkatkan kompetensi pedagogik guru untuk meningkatkan mutu sekolah dapat dilakukan dengan beberapa cara diantaranya melalui MGMP (Musyawarah Guru Mata Pelajaran), kursus kependidikan, workshop, supervisi dan rapat sekolah (Saryati, 2014: 678680). Seperti pada penelitian yang dilakukan oleh Suhaemi \& Aedi (2015: 241-254) yang menyatakan bahwa mengikut sertakan dosen dalam berbagai kegiatan ilmiah, seminar, simposium, workshop dan publikasi ilmiah baik secara nasional maupun jurnal internasional dapat meningkatkan kompetensi pedagogik Dosen. Hal tersebut terlihat dari lulusan yang bermutu dengan indeks prestasi mahasiswa yang tinggi dan karya dosen dalam menulis buku meningkat, dosen juga menjadi handal dalam menggunakan multimedia dalam pembelajaran. Selain itu pemanfaatan teknologi dan komunikasi juga dapat meningkatkan kompetensi pedagogik (Liu 2011; Donnelly, dkk., 2011 dalam Khan, 2014: 21-31). Peningkatan kompetensi pedagogik lainnya dapat dilakukan melalui sikap saling belajar antar guru dan mengadakan lesson study (Tedjawati, 2011: 483), action research, study groups, case discussion dan lesson study (Department of Education \& Training, 2005: 10). Dalam meningkatkan kompetensi pedgogik guru juga diperlukan peran pemimpin untuk dapat membangkitkan motivasi guru dan dorongan untuk mencapai tujuan bersama (Musadad, 2010: 145), selain peran pemimpin, peran siswa perlu dilibatkan dalam meningkatkan kompetensi pedagogik guru karena dengan kerja sama guru dan siswa, maka guru dapat memahami pola pikir siswa dan mengembangkan pembelajarannya (Fullan \& Langworthy, 2014: 11). Dukungan eksternal akan membantu meningkatkan kompetensi pedagogik guru, seperti dukungan dari pemerintah atau dinas pendidikan dengan melakukan pelatihan, bantuan finansial, mentoring dan evaluasi (Wilson. 2009: 1-9).

Kompetensi pedagogik penting ditingkatkan untuk meningkatkan mutu sekolah, dan hal tersebut penting untuk dilakukan di SMA Swasta Berasrama di Kabupaten Semarang yang memiliki murid dari berbagai daerah dari berbagai penjuru Indonesia. Peningkatan kompetensi pedagogik guru ini penting karena sekolah ini sudah memiliki rencana untuk meningkatkan dan mengembangkan fasilitas sarana dan prasarana dari tahun ke tahun secara berkelanjutan, dan program promosi yang semakin berkembang. Namun, belum ada program untuk meningkatkan kualitas guru yang terencana dengan jelas baik dari pihak sekolah maupun dari pihak yayasan. Belum adanya rencana strategis untuk meningkatkan kompetensi pedagogik guru ini mempengaruhi kinerja guru pada saat proses belajar mengajar, dimana pengajaran masih student centered, kurangnya kreatifitas dan inovasi guru pada saat mengajar. Hal tersebut juga mempengaruhi lulusan SMA ini, dimana untuk rumpun IPA selalu masuk peringkat 3 besar di kabupaten, sedangkan untuk rumpun IPS masih belum stabil untuk berada di peringkat 5 besar kabupaten. Oleh sebab itu, rencana strategi peningkatkan kompetensi pedagogik bagi sekolah ini sangatlah penting untuk meningkatkan mutu sekolah. Dalam rangka mengembangkan rencana strategi itulah penelitian ini dilakukan.

\section{METODE PENELITIAN}

Penelitian ini merupakan penelitian dan pengembangan (Research and Development) dengan menggunakan langkah-langkah dari Sugiyono, namun hanya sampai pada tahap ketujuh, yaitu: 1) potensi dan masalah; 2) pengumpulan data; 3) desain produk; 4) validasi desain; 5) revisi desain; 6) uji kelayakan; dan 7) revisi produk. Penelitian dilakukan disebuah SMA Swasta berasrama di 
Kabupaten Semarang dengan subjek kepala sekolah, wakil kepala sekolah, 1 guru bidang studi pengetahuan alam, 2 guru bidang studi sosial, 2 guru bidang studi bahasa, dan 1 guru bidang studi umum.

Data diperoleh melalui wawancara, observasi, dan studi dokumen. Analisa data yang digunakan dalam penelitian ini menggunakan analisis SWOT (Strength, Weakness, Opportunity, and Threat), dan dengan menggunakan analisis matrix IFAS (Internal Factor Analysis Summary) dan EFAS (External Factor Analysis Summary).

\section{HASIL PENELITIAN}

Analisis SWOT yang dilakukan dengan menganilisis faktor internal, yaitu kekuatan dan kelemahan, serta faktor eksternal yaitu peluang dan ancaman melalui diskusi bersama dengan para sumber/subjek penelitian, dan kemudian dianalisis dengan menggunakan matriks IFAS dan EFAS. Hasil analisis faktor internal dan eksternal kemudian diberikan bobot dan rating, kemudian dihitung skor akhirnya untuk mengetahui nilai dari setiap faktor yang nantinya akan menunjukan posisi yang dimiliki oleh sekolah, apakah berada di kuadaran SO (Strength Opportunity), kuadran ST (Strength Threats), kuadran WO (Weakness Opportunity), atau kuadran WT (Weakness Threat). Hasil analisis faktor internal, kekuatan dan ancaman adalah sebagai tertera dalam tabel 2 berikut ini.

Tabel 2. Matrix IFAS (Internal Factors Analysis Summary)

\begin{tabular}{|c|c|c|c|c|}
\hline No. & Kekuatan & Bobot & Rating & Bobot X Rating \\
\hline 1 & Fasilitas sekolah sudah memadai & 0.15 & 4 & 0.6 \\
\hline 2 & Sekurang-kurangnya $80 \%$ guru sudah bergelar sarjana & 0.1 & 3 & 0.3 \\
\hline 3 & Beberapa guru masih muda dengan jenjang karir yang panjang & 0.15 & 3 & 0.45 \\
\hline 4 & Kesejahteraan guru terjamin & 0.1 & 2 & 0.2 \\
\hline 5 & Guru mengajar sesuai dengan bidangnya & 0.1 & 3 & 0.3 \\
\hline 6 & $\begin{array}{l}\text { Guru akrab dengan murid dan memberikan kesempatan belajar yang sama } \\
\text { terhadap peserta didik }\end{array}$ & 0.1 & 3 & 0.3 \\
\hline 7 & $\begin{array}{l}\text { Guru membuat administrasi pembelajaran dan penilaian serta silabus yang sesuai } \\
\text { dengan kurikulum }\end{array}$ & 0.05 & 1 & 0.05 \\
\hline 8 & $\begin{array}{l}\text { Guru-guru mata pelajaran IPA metode pembelajarannya lebih variatif dan } \\
\text { inovatif }\end{array}$ & 0.1 & 2 & 0.2 \\
\hline 9 & $\begin{array}{l}\text { Beberapa guru pengampu mata pelajaran UN IPA berhasil mengajar dan } \\
\text { membimbing siswanya dalam persiapan UN sehingga nilai UN masuk } 3 \text { besar } \\
\text { kabupaten. }\end{array}$ & 0.05 & 2 & 0.1 \\
\hline 10 & Loyalitas guru tinggi & 0.1 & 3 & 0.3 \\
\hline & TOTAL & 1 & 26 & 2.8 \\
\hline No. & Kelemahan & Bobot & Rating & Bobot X Rating \\
\hline 1 & $\begin{array}{l}\text { Manajemen dalam organisasi kurang maksimal sehingga program yang disusun } \\
\text { belum nampak pencapaian kompetensinya }\end{array}$ & 0.2 & 1 & 0.2 \\
\hline 2 & $\begin{array}{l}\text { Penerimaan guru mengutamakan untuk yang beragama Nasrani, dan untuk } \\
\text { kompetensi pedagogik guru dapat menyusul }\end{array}$ & 0.1 & 3 & 0.3 \\
\hline 3 & $\begin{array}{l}\text { Pembinaan guru dalam bidang kompetensi pedagogik dan profesionalisme } \\
\text { kurang }\end{array}$ & 0.15 & 2 & 0.3 \\
\hline 4 & $\begin{array}{l}\text { Pekerjaan guru diluar kelas (jam mengajar) cukup banyak (mengurus kegiatan- } \\
\text { kegiatan sekolah) }\end{array}$ & 0.1 & 4 & 0.4 \\
\hline 5 & $\begin{array}{l}\text { Guru pengampu mata pelajaran IPS dan umum masih ada yang mengajarnya } \\
\text { standar/biasa saja, kurang kreatif dan inovasi }\end{array}$ & 0.1 & 2 & 0.2 \\
\hline 6 & $\begin{array}{l}\text { Pengembangan kurikulum masih standar (masih sama seperti kurikulum dari } \\
\text { pemerintah) untuk mata pelajaran IPS dan umum }\end{array}$ & 0.1 & 2 & 0.2 \\
\hline 7 & Beberapa guru masih minim dalam penguasaan kelas & 0.15 & 2 & 0.3 \\
\hline \multirow[t]{2}{*}{8} & $\begin{array}{l}\text { Hasil UN mata pelajaran IPS masih standard dan masih belum maksimal (belum } \\
\text { stabil dalam menempati peringkat } 5 \text { besar kabupaten) }\end{array}$ & 0.1 & 4 & 0.4 \\
\hline & TOTAL & 1 & 20 & 2.3 \\
\hline
\end{tabular}


Kelola: Jurnal Manajemen Pendidikan, Vol. 5, No. 2, Juli-Desember 2018

Berdasarkan tabel tersebut dapat ditarik kesimpulan bahwa nilai bobot dikalikan dengan skor pada faktor kekuatan adalah 2.8 dan pada faktor kelemahan adalah 2.3, sehingga nilai akhir IFAS yaitu faktor kekuatan dikurangi faktor kelemahan didapat 0.5. Hal ini menunjukan bahwa faktor kekuatan lebih dominan dari pada faktor kelemahan yang dimiliki oleh sekolah.

Kemudian, hasil dari analisis EFAS adalah sebagai tertera dalam table 3berikut ini.

Tabel 2. Matrix EFAS (External Factors Analysis Summary)

\begin{tabular}{|c|c|c|c|c|}
\hline No. & 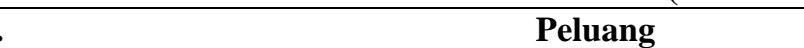 & \multicolumn{3}{|c|}{ Bobot Rating Bobot X Rating } \\
\hline 1 & Animo masyarakat terhadap sekolah tinggi & 0.2 & 3 & 0.6 \\
\hline 2 & Jumlah murid meningkat setiap tahunnya & 0.2 & 3 & 0.6 \\
\hline 3 & Sekolah berasrama & 0.3 & 4 & 1.2 \\
\hline 4 & Hubungan dengan gereja dan beberapa SMP swasta baik & 0.1 & 1 & 0.1 \\
\hline 5 & Adanya program sertifikasi guru dari pemerintah & 0.1 & 2 & 0.2 \\
\hline \multirow[t]{2}{*}{6} & Dukungan dari pemerintah & 0.1 & 2 & 0.2 \\
\hline & TOTAL & 1 & 13 & 2.9 \\
\hline No. & Ancaman & \multicolumn{3}{|c|}{ Bobot Rating Bobot X Rating } \\
\hline 1 & Sekolah Negeri yang semakin baik & 0.3 & 3 & 0.9 \\
\hline 2 & Munculnya sekolah-sekolah berasrama di sekitar SMA & 0.4 & 1 & 0.4 \\
\hline 3 & Jumlah murid yang berasal dari sekitar menurun & 0.2 & 2 & 0.4 \\
\hline & Program KB (Keluarga Berencana) dari pemerintah & 0.1 & 4 & 0.4 \\
\hline & $\begin{array}{ll}\text { TOTAL } \\
\end{array}$ & 1 & 10 & 2.1 \\
\hline
\end{tabular}

Sumber: Data Penelitian

Analisis dari matrik EFAS menunjukan bahwa total pada peluang adalah 2.9 dan ancaman adalah 2.1, sehingga skor akhir pada matrik EFAS adalah peluang dikurangi ancaman, 0.8. Hal ini menunjukan bahwa faktor peluang yang dimiliki oleh sekolah lebih dominan dan dapat dioptimalkan untuk meningkatkan kompetensi pedagogik guru. Berdasarkan analisis SWOT tersebut diketahui skor akhir matrik IFAS adalah 0.5 dan skor akhir matrik EFAS adalah 0.8, sehingga hasil akhir menunjukan bahwa strategi berada di kuadran SO (Strength Opportunity). Strategi yang digunakan oleh sekolah nantinya adalah strategi yang mengoptimalkan kekuatan dan peluang yang dimiliki oleh sekolah. Hasil analisis tersebut ditunjukan melalui matrik SWOT berikut:

Table 3. Skor Akhir Matrik SWOT

\begin{tabular}{cccc}
\hline \multicolumn{2}{c}{ IFAS } & \multicolumn{2}{c}{ EFAS } \\
\hline Kategori & Total skor & Kategori & Total skor \\
\hline Kekuatan $($ S) & 2,8 & Peluang $(\mathrm{O})$ & 2,9 \\
\hline Kelemahan $(\mathrm{W})$ & 2,3 & Ancaman $(\mathrm{T})$ & 2,1 \\
\hline Total $(\mathrm{S}-\mathrm{W})$ & $\mathbf{0 , 5}$ & Total $(\mathbf{O}-\mathbf{T})$ & $\mathbf{0 , 8}$ \\
\hline
\end{tabular}

Sumber: Data penelitian
Dari hasil penelitian tersebut dapat ditarik hasil bahwa faktor kekuatan internal sekolah dan peluang eksternal sekolah lebih kuat untuk meningkatkan mutu sekolah. Oleh sebab itu dari hasil penelitian tersebut dapat dianalisis strategi yang dapat dilakukan untuk meningkatkan kompetensi pedagogik guru untuk meningkatkan mutu sekolah dalam penelitian ini ada 5, yaitu:

- Strategi pertama: mengoptimalkan kolaborasi antar guru

- Strategi kedua: mengoptimalkan kolaborasi antar guru dan siswa

- Strategi ketiga: mengoptimalkan dukungan dari pihak eksternal (yayasan dan dinas)

- Strategi keempat: mengoptimalkan profesionalisme dan kualitas guru

- Strategi kelima: meningkatkan kerja sama pengajar, murid, dan orang tua

Yang pertama adalah mengoptimalkan kolaborasi antar guru yang dapat dilakukan diantaranya dengan melakukan beberapa kegiatan seperti case discussion, action research, study groups dan lesson study 
(Departement of Education \& Training, 2005: 10; Tedjawati, 2011: 483). Selain itu, dapat juga dilakukan kunjungan antar kelas, sehingga guru dapat saling belajar mengenai metode mengajar maupun keadaan kelas dari rekan guru lainnya (Saryati, 2014: 678-680).

Kedua adalah mengoptimalkan kolaborasi antar guru dan siswa. Hubungan yang baik antara guru dan murid akan membuat guru akan lebih memahami keadaan kelas dan murid-muridnya, bagaimana muridnya berpikir, karakter muridnya dan bagaimana murid-muridnya berinteraksi satu sama lain, sehingga guru dapat memilih metode mengajar yang tepat dan sesuai. Hal tersebut dapat membuat suasana belajar menjadi lebih kondusif, suasana belajar menjadi lebih komunal, dan memperkuat kesetiaan atau ketaatan (OECD, 2010: 88-98). Selain itu, menurut Fullan \& Langworthy (2014: 11) saat ini, siswa ingin terlibat aktif dalam pembelajaran, sehingga untuk menciptakan suasana belajar yang aktif dan kreatif maka guru harus dapat bekerja sama dengan muridnya.

Ketiga, mengoptimalkan dukungan dari pihak eksternal (Yayasan dan Dinas). Pada penelitian yang dilakukan oleh Suhaemi dan Aedi (2015: 241), dukungan dari pemerintah terhadap rencana strategi untuk meningkatkan kompetensi profesional dosen merupakan salah satu faktor keberhasilan dari program pengembangan kompetensi pedagogik dan profesional dosen. Bantuan atau dorongan dari pemerintah, instansi Dinas atau Universitas dapat berupa memberikan pelatihan atau seminar kepada guru terkait dengan pembelajaran, mentoring dan meningkatkan penilain guru supaya guru dapat terus meningkatkan kualitasnya (Wilson, 2009: 1-9). Kemudian, upaya ini didukung oleh penelitian dari Ramdass \& Masithulela (2016: 13) dimana dalam penelitiannya ditemukan bahwa dukungan dari pemerintah dan industri untuk meningkatkan kompetensi pedagogik guru itu penting.

Berikutnya adalah mengoptimalkan profesionalisme dan kualitas guru. Program ini merupakan sarana bagi guru untuk meningkatkan dan mengembangkan kompetensi pedagogiknya melalui beberapa upaya dapat dilakukan oleh lembaga atau sekolah untuk meningkatkan kompetensi pedagogik guru, seperti dengan mengadakan lokakarya (workshop), dan mengadakan penataran guru (Saryati, 2014: 678-680). Selain itu, guru juga dapat mengikuti seminar, workshop, dan menerbitkan jurnal baik nasional ataupun internasional untuk meningkatkan kompetensi pedagogiknya (Suhaemi \& Aedi, 2015: 242). Penggunaan teknologi informasi dan komunikasi juga dapat digunakan untuk meningkatkan kualitas mengajar guru (Liu 2011; Donnelly, dkk., 2011 dalam Khan, 2014: 21).

Meningkatkan kerja sama pengajar, murid, dan orang tua juga dapat menjadi strategi untuk meningkatkan mutu sekolah. Suasana belajar mengajar dan juga suasana sekolah akan semakin lebih kondusif dan performa siswa akan meningkat jika guru dan murid memiliki hubungan yang baik dan mendapatkan dukungan dari orang tua. Peran orang tua merupakan salah satu faktor yang mempengaruhi performa siswa (OECD, 2010: 88-89).

\section{Pembahasan}

Berdasarkan analisis SWOT, maka didapatkan lima strategi yang dapat dilakukan untuk meningkatkan kompetensi pedagogik guru dalam rangka meningkatkan mutu sekolah, yaitu:

Strategi Pertama, adalah mengoptimalkan kolaborasi antar guru. Berdasarkan hasil analisa SWOT pada faktor eksternal dan internal SMA Sedes Sapientiae Jambu terlihat bahwa loyalitas guru dan keakraban antar guru tinggi. Poin tersebut dapat dioptimalkan untuk mendukung peningkatan 
Kelola: Jurnal Manajemen Pendidikan, Vol. 5, No. 2, Juli-Desember 2018

kompetensi pedagogik guru. Kolaborasi antar guru yang dapat dilakukan diantaranya dengan melakukan beberapa kegiatan seperti case discussion, action research, study groups dan lesson study (Departement of Education \& Training, 2005: 10; Tedjawati, 2011: 483). Selain itu, dapat juga dilakukan kunjungan antar kelas, sehingga guru dapat saling belajar mengenai metode mengajar maupun keadaan kelas dari rekan guru lainnya (Saryati, 2014: 678-680). Kegiatan yang dapat dilakukan cukup banyak, yaitu sharing teman sejawat (sharing edukatif) mengenai metode mengajar, nilai-nilai pengetahuan, keadaan kelas dan kondisi siswa, action research, study group, case discussion, kunjungan antar kelas supaya guru dapat saling belajar dan menilai mengenai metode mengajar yang dilakukan oleh rekannya, team teaching dan lesson study. Dengan mengoptimalkan kolaborasi antar guru ini dapat membantu guru untuk saling bertukar pikiran secara edukatif dan saling belajar dengan lebih santai karena para guru sudah akrab dan terbiasa. Program kegiatan untuk mengoptimalkan kolaborasi antar guru adalah dengan sharing teman sejawat, action research (penelitian tindakan) yang ditindak lanjuti dengan pembuatan karya ilmiah nantinya, study group, case discussion, kunjungan antar kelas, team teaching, dan lesson study.

Strategi Kedua adalah kolaborasi antar guru dan siswa. Kompetensi pedagogik merupakan kemampuan pengenalan peserta didik (Sagala, 2011: 32), selain itu, kompetensi pedagogik guru perlu dimiliki oleh guru salah satunya untuk mendiagnosis berbagai hambatan dan masalah yang dihadapi oleh peserta didik (Soedijarto, 2008: 199). Oleh sebab itu, guru perlu untuk memiliki hubungan yang baik untuk membantu meningkatkan kompetensi pedagogik guru, terlebih guru-guru di SMA Sedes Sapientiae Jambu sudah akrab dan memiliki hubungan yang baik dengan murid-murid, sehingga hal tersebut dapat lebih dioptimalkan. Hubungan yang baik antara guru dan murid akan membuat guru akan lebih memahami keadaan kelas dan murid-muridnya, bagaimana muridnya berpikir, karakter muridnya dan bagaimana murid-muridnya berinteraksi satu sama lain, sehingga guru dapat memilih metode mengajar yang tepat dan sesuai. Hal tersebut dapat membuat suasana belajar menjadi lebih kondusif, suasana belajar menjadi lebih komunal, dan memperkuat kesetiaan atau ketaatan (OECD, 2010: 88-98). Selain itu, menurut Fullan \& Langworthy (2014: 11) saat ini, siswa ingin terlibat aktif dalam pembelajaran, sehingga untuk menciptakan suasana belajar yang aktif dan kreatif maka guru harus dapat bekerja sama dengan muridnya. Kegiatan yang dapat membantu guru untuk meningkatkan kompetensi pedagogiknya diantaranya dengan evaluasi harian, evaluasi mingguan dan evaluasi diakhir semester. Keakraban dan kerja sama antar guru dan siswa akan membantu guru untuk memahami karakter siswanya, sehingga guru dapat memberikan pengajaran yang membuat para siswa tertarik dan kreatif. Beberapa kegiatan yang dilakukan adalah evaluasi harian, evaluasi mingguan, dan evaluasi akhir semester yang nantinya hasil evaluasi tersebut akan menjadi penilaian guru favorit atau guru berprestasi.

Strategi Ketiga, mengoptimalkan dukungan dari pihak eksternal (Yayasan dan Dinas). Pada penelitian yang dilakukan oleh Suhaemi dan Aedi (2015: 241), dukungan dari pemerintah terhadap rencana strategi untuk meningkatkan kompetensi profesional dosen merupakan salah satu faktor keberhasilan dari program pengembangan kompetensi pedagogik dan profesional dosen. Oleh sebab itu, memanfaatkan peluang dari SMA Sedes Sapientiae Jambu yang memiliki hubungan yang baik dengan Pemerintah (Dinas), maka hubungan tersebut dapat terus dioptimalkan. Bantuan atau dorongan dari pemerintah, instansi Dinas atau Universitas dapat berupa memberikan pelatihan atau seminar kepada 
guru terkait dengan pembelajaran, mentoring dan meningkatkan penilain guru supaya guru dapat terus meningkatkan kualitasnya (Wilson, 2009: 1-9). Kemudian, upaya ini didukung oleh penelitian dari Ramdass \& Masithulela (2016: 13) dimana dalam penelitiannya ditemukan bahwa dukungan dari pemerintah dan industri untuk meningkatkan kompetensi pedagogik guru itu penting. Dengan adanya dukungan dan kerja sama dari pemerintah dan industri, maka sekolah akan mengetahui kebutuhan dari pemerintah dan industri, sehingga nantinya sekolah dapat membuat kurikulum untuk mencapai kebutuhkan sosial yang dapat memenuhi tenaga kerja (lulusan yang berkualitas sesuai kebutuhan stakeholder). Dukungan secara eksternal dari yayasan dan dinas dapat berupa dukungan dalam evaluasi guru, seperti bantuan atau dukungan untuk guru supaya hasil tes UKG bisa lebih baik, melihat hasil tes UKG dimana guru di SMA Sedes Sapientiae Jambu kebanyakan masih berada dibawah nilai minimal. Maka mengoptimalkan penilaian guru dari pihak yayasan ataupun Dinas dapat membantu guru untuk lebih memahami dan mempraktekan kompetensi pedagogik dan profesionalisme yang harus dimiliki oleh guru. Kegiatan yang akan dilakukan adalah dengan pengadaan pelatihan, seminar, workshop, pertemuan MGMP, dan simulasi tes UKG.

\section{Strategi Keempat, adalah} mengoptimalkan profesionalisme dan kualitas guru. Program ini merupakan sarana bagi guru untuk meningkatkan dan mengembangkan kompetensi pedagogiknya melalui beberapa upaya dapat dilakukan oleh lembaga atau sekolah untuk meningkatkan kompetensi pedagogik guru, seperti dengan mengadakan lokakarya (workshop), dan mengadakan penataran guru (Saryati, 2014: 678-680). Selain itu, guru juga dapat mengikuti seminar, workshop, dan menerbitkan jurnal baik nasional ataupun internasional untuk meningkatkan kompetensi pedagogiknya
(Suhaemi \& Aedi, 2015: 242). Penggunaan teknologi informasi dan komunikasi juga dapat digunakan untuk meningkatkan kualitas mengajar guru (Liu 2011; Donnelly, dkk., 2011 dalam Khan, 2014: 21). Beberapa kegiatan peningkatan kompetensi pedagogik guru tersebut dirangkum dalam kegiatan pelatihan, baik pelatihan dan seminar metode mengajar maupun pelatihan pemanfaatan media teknologi dan e-learning, dan workshop. Kegiatan tersebut dapat dilakukan dengan bekerja sama dengan pihak luar seperti pemerintah, universitas atau instansi pendidikan lainnya sebagai sponsor kegiatan maupun membantu dalam penyelenggaran kegiatan tersebut, atau menjadi pelatih atau pembicara dalam kegiatan tersebut. Mengoptimalkan kegiatan pengembangan pedagogik guru ini dapat dilakukan dengan bekerja sama dengan beberapa instansi pendidikan lainnya, pemerintah, atau universitas mitra. Dalam strategi keempat ini, kegiatan yang dilakukan adalah pelatihan, seminar, lokakarya dan karya ilmiah guru dengan adanya pelatihan karya ilmiah, dan ajang kompetensi.

Strategi Kelima meningkatkan kerja sama pengajar, murid, dan orang tua. Suasana belajar mengajar dan juga suasana sekolah akan semakin lebih kondusif dan performa siswa akan meningkat jika guru dan murid memiliki hubungan yang baik dan mendapatkan dukungan dari orang tua. Peran orang tua merupakan salah satu faktor yang mempengaruhi performa siswa (OECD, 2010: 88-89). Dengan adanya peran orang tua maka siswa akan merasa terdorong dan termotivasi dengan dukungan orang tua, sehingga nantinya performa siswa akan lebih baik. Melibatkan orang tua dalam peningkatan kompetensi pedagogik guru dapat membantu guru untuk mendapatkan umpan balik dari para orang tua, dimana orang tua dapat memberikan masukan kepada guru mengenai kondisi anaknya sehingga guru dapat lebih memahami anaknya 
Kelola: Jurnal Manajemen Pendidikan, Vol. 5, No. 2, Juli-Desember 2018

dan begitu pula sebaliknya, dimana guru dapat memberikan masukan kepada orang tua mengenai kondisi anaknya sehingga orang tua dapat mendukung anaknya dengan optimal. Program ini dapat lebih dioptimalkan dengan adanya web sekolah dan sms gateaway dimana kegiatan sekolah selalu diberitahukan oleh pihak sekolah kepada orang tua dan ditampilkan dalam web sekolah, sehingga orang tua mengetahui kegiatan yang terjadi disekolah. Kegiatan yang dapat dilakukan dalam program kemitraan orang tua dan komite yaitu meliputi kegiatan evaluasi akhir semester bersamaan dengan evaluasi akhir semester siswa, dan pemberian penghargaan kepada guru supaya guru lebih termotivasi dalam mengajar. Dalam program kemitraan orang tua dan komite ini dapat dilakukan kemitraan keluarga. Kerjasama antar pengajar ini dapat dioptimalkan untuk memotivasi guru supaya pembelajaran yang dilakukan oleh guru dapat lebih maksimal, bervariatif, dan inovatif. Siswa juga dapat berperan aktif untuk memberikan penilaian kepada guru, sehingga guru akan menerima masukan dari para murid untuk pembelajaran yang lebih baik lagi. Beberapa kegiatan yang dilakukan pada strategi kelima ini adalah dengan evaluasi akhir semester dan adanya teacher award atau penghargaan kepada guru.

\section{SIMPULAN DAN SARAN}

\section{Simpulan}

Dalam upaya menentukan strategi peningkatan kompetensi pedagogik guru di sekolah menengah atas berasrama di kabupaten Semarang, terdapat beberapa faktor internal (kekuatan - kelemahan) dan eksternal (peluang-ancaman) yang dimiliki oleh sekolah. Faktor-faktor itu telah dianalisis menggunakan SWOT dan hasil akhir dari analisis SWOT adalah kekuatan lebih tinggi dari pada kelemahan, dan peluang yang dimiliki oleh sekolah lebih tinggi dari pada ancaman. Oleh karena itu, sekolah ini berada pada kuadran SO
(Strength-Opportunity), yang berarti dalam merencanakan strategi peningkatan kompetensi pedagogik guru, sekolah menggunakan strategi agresif dengan memanfaatkan kekuatan yang dimiliki untuk menangkap peluang yang ada.

Faktor kekuatan yang dimiliki oleh sekolah diantaranya adalah fasilitas sekolah yang memadai, sekurang-kurangnya $80 \%$ guru sudah bergelar sarjana, beberapa guru masih muda dengan jenjang karir yang panjang, kesejahteraan guru terjamin, guru mengajar sesuai bidangnya, guru akrab dengan murid dan memberikan kesempatan belajar yang sama terhadap peserta didik, guru telah membuat administrasi pembelajaran, penilaian, serta silabus yang sesuai dengan kurikulum, guruguru mata pelajaran IPA memiliki metode mengajar yang lebih variatif dan inovatif, beberapa guru mata pelajaran IPA berhasil mengajar dan membimbing siswanya dalam persiapan UN sehingga nilai UN selalu masuk 3 besar di kabupaten, dan loyalitas guru terhadap kemajuan sekolah tinggi. Sedangkan faktor peluang yang dimiliki sekolah adalah animo masyarakat terhadap sekolah tinggi, jumlah murid meningkat setiap tahunnya, sekolah berasrama, hubungan dengan gereja dan SMP swasta baik, adanya program sertifikasi dari pemerintah dan dukungan dari pemerintah (dinas).

Oleh karena itu strategi yang dapat dilakukan untuk meningkatkan kompetensi pedagogik guru untuk meningkatkan mutu sekolah dalam penelitian ini ada 5, yaitu: a) mengoptimalkan kolaborasi antar guru, b) mengoptimalkan kolaborasi antar guru dan siswa, c) mengoptimalkan dukungan dari pihak eksternal (yayasan dan dinas), d) mengoptimalkan profesionalisme dan kualitas guru, dan e) meningkatkan kerja sama pengajar, murid, dan orang tua. Kelima strategi tersebut dapat dilakukan dalam jangka panjang dan berkala sesuai dengan keadaan dan kondisi sekolah. Dalam pelaksanaan program operasional sekolah tersebut melibatkan peran 
Strategi Peningkatan Kompetensi Pedagogik Guru Untuk ... | Brigitta P. A. Tyagita

serta dari yayasan atau dinas sebagai supervisor, kepala sekolah sebagai penanggung jawab, wakil kepala sekolah sebagai ketua pelaksana, guru sebagai pelaksana dan juga peserta, dan komite sebagai pendukung.

\section{Saran}

Berdasarkan hasil penelitian, saran yang dapat diberikan bagi sekolah adalah merencanakan, melaksanakan, mengevaluasi program peningkatan kompetensi pedagogik guru di sekolah guna tercapainya tujuan sekolah, membentuk tim pengembangan dan peningkatan kompetensi pedagogik guru untuk peningkatan mutu sekolah, dan menjalin kerja sama dan komunikasi dengan instansi-instansi atau pihak lainnya seperti universitas atau dinas pendidikan untuk pelatihan atau workshop untuk guru.

Sedangkan saran bagi kepala sekolah hendaknya memiliki gaya kepemimpinan yang tegas, sehingga dapat membantu mengarahkan guru untuk lebih baik dan hendaknya memotivasi guru untuk meningkatkan kompetensi pedagogiknya dan untuk menulis karya ilmiah untuk diterbitkan atau diseminarkan secara nasional ataupun internasional.

Saran bagi guru hendaknya memiliki kemauan tinggi untuk meningkatkan kompetensi pedagogik dan profesionalisme, sehingga kinerjanya akan semakin meningkat, mempunyai kemauan yang tinggi untuk mengikuti dan mengapikasikan hasil seminar atau workshop atau pelatihan yang lain dalam proses belajar mengajarnya dan memiliki loyalitas yang tinggi dalam memajukan sekolah dan memiliki keakraban antar guru maupun siswa. Untuk penelitian yang lebih lanjut dapat diperdalam mengenai peningkatan kompetensikompetensi guru yang lain guna meningkatkan mutu sekolah.

\section{DAFTAR PUSTAKA}

CIRR ICD. 2005. Capacity Building for Local NGOs: A Guidance Manual for Good Practice. London: Catholic Institute for
International Relation. Retrieved from http://www.progressio.org.uk/sites/progressio.o rg.uk/files/3_Strategicplanning.pdf

Danim, S. 2010. Otonomi Manajemen Sekolah. Bandung: Alfabeta.

Departement of Education \& Training. 2005. Professional Learning in Effective Schools: The Seven Principles of Highly Effective Professional Learning. Melbourne: Leadership and Teacher Development Branch. Retrieved from http://www.sofweb.vic.edu.au/blueprint/fs5/def ault.asp

Fahruddin, I. 2016, Desember 15. Kualitas Pendidikan Indonesia. Retrieved 12 22, 2016, from Tentang Nusantara: http://www.tentangnusantara.com/kualitaspendidikan-indonesia.html

Fullan, M., \& Langworthy, M. 2014. A Rich Seam: How New Pedagogies Find Deep Learninng. California: Pearson.

Guerriero, Sonia. 2013. Teachers' Pedagogical Knowledge and the Teaching Profession Background Report and Project Objectives. OECD (Better Policies For Better Lives)

Hakim, A. 2015. Contribution of Comptence Teacher (pedagogical, Personality, Professional Competence and Social) On the Performance of Learning. The International Journal of Engineering and Science (IJES), 4 (2), 1-12.

Inan, Kito. 2016, January 24. Permasalahan Guru di Indonesia Sekarang. Retrieved December 20, 2016, from Inan Kito Konsultan: Konsultan Pendidikan dan Sains

Dasar: http://www.inankito.org/2016/01/perm asalahan-guru-di-indonesiasekarang.html

Juddy, Farrah. 2014. Best Practice: Strategic Planning. Arlington Blvd: Foundation for Community Association Research. 
Kelola: Jurnal Manajemen Pendidikan, Vol. 5, No. 2, Juli-Desember 2018

Kementrian Pendidikan Nasional. 2010. Pedoman Pelaksanaan Penilaian Kinerja Guru (PK Guru). Direktorat Jenderal Peningkatan Mutu Pendidik dan Tenaga Kependidikan. Retrieved from www.bermutuprofesi.org

Khan, S. H. 2014. A Model for Integrating ICT into Teacher Training Programs in Bangladesh based on TPCK. International journal of education adn development using information and communication technology, 10, Issue 3, 21-31.

Musadad, A. A. 2010. Peran Kepemimpinan, Etos Kerja, dan Persepsi Kepala Sekolah Terhadap Mutu Pendidikan. Paedagogia, 145.

OECD. 2005. Education at a Glance 2010: OECD Indicators. Paris: OECD Publishing.

Panda, S. 2012. Mapping Pedagogical Competency of Secondary School Science Teacher: An Attempt and Analysis. International E-Journal (Quarterly), 1 (4), 32-45. Retrieved from www.oiirj.org

Peraturan Menteri Pendidikan Nasional No. 16 Tahun 2007 tentang Standar Kualifikasi Akamdemik dan Kompetensi Guru.

Peraturan Pemerintah No. 19 Tahun 2005 tentang Standar Nasional Pendidikan.

Rahman, M. H. 2014. Professional Competence, Peagogical Competence and the Performance of Junior High School of Science Teachers. Journal of Education and Practice, 5 (9), 75-80. Retrieved from www.iiste.org

Ramdass, K. \& Mashitulela, F. J. 2016. Comparative Analysis of Pedagogical Strategies Across Disciplines in Open Distance Learning at Unisa.
International Review of Research in Open and Distributed Learning, 17 (2).

Retrieved from www.irrodl.org

Rangkuti, F. 2016. Analisis SWOT: Teknik Membedah Kasus Bisnis. Jakarta: PT. Gramedia.

Sagala, S. 2011. Konsep dan Makna Pembelajaran. Bandung: Alfabeta.

Sani, R., \& Abdullah, D. 2015. Penjamin Mutu Sekolah. (N. Syamsiyah, Ed.) Jakarta: Bumi Aksara.

Saryati. 2014. Upaya Peningkatan Kompetensi Pedagogik Guru Sekolah Dasar. Jurnal Administrasi Pendidikan, 2 (1). Retrieved from www.ejournal.unp.ac.id

Soedijarto. 2008. Landasan dan Arah Pendidikan Nasional Kita. Jakarta: Kompas.

Suhaemi, M. E., \& Aedi, N. 2015. A Management Strategy for the Imrpovement of Private Universities Lectures' Professional Competencies. International Education Studies, 8(12), 241-254. doi:10.5539/ies.v8n12p241

Tedjawati, J. M. 2011. Peningkatan Kompetensi Guru Melalui Lesson Studi: Kasus di Kabupaten Bantul. Jurnal Pendidikan dan Kebudayaan, 17 (4), 480-489.

Umiarso, \& Gozali, I. 2010. Manajemen Mutu Sekolah di Era Otonomi Pendidikan. Jogjakarta: IRCiSoD

Uppsala University. 2010. A Swedish Perspective on Pedagogical Competence. (A. R. Apelgren, Ed., \& R. Eriksson, Trans.) Swedish: Uppsala University.

Wilson, S. (Ed.). 2009. Teacher Quality: Education Policy White Paper. National Academy and Education, 1-9. 